\title{
Growth and quality of potted ornamental peppers treated with paclobutrazol
}

\author{
Christiane de Fátima Martins França(1), Wellington Souto Ribeiro(2), Mirelle Nayana Sousa Santos(3), \\ Kharen Priscilla de Oliveira Salomão Petrucci( ${ }^{(4)}$, Elizanilda Ramalho do Rêgo ${ }^{(5)}$ and Fernando Luiz Finger ${ }^{(4)}$
}

\begin{abstract}
(1)Universidade Federal do Oeste da Bahia, Centro Multidisciplinar da Barra, Avenida 23 de Agosto s/no, Bairro Assunção, CEP 47100-000 Barra, BA, Brazil. E-mail: christiane.franca@ufob.edu.br (2)Universidade Estadual da Paraíba, Campus II, Departamento de Agroecologia e Agropecuária, Sítio Imbaúba, s/nº, CEP 58117-000 Lagoa Seca, PB, Brazil. E-mail: wellingtisouto@yahoo.com.br (3)Universidade Federal de Viçosa, Departamento de Biologia Vegetal, Avenida Peter Henry Rolfs s/no, CEP 36570-900 Viçosa, MG, Brazil. E-mail: mirellebio@hotmail.com ${ }^{(4)}$ Universidade Federal de Viçosa, Departamento de Fitotecnia, Avenida Peter Henry Rolfs, s/nó, CEP $36570-900$ Viçosa MG, Brazil. E-mail: kharensalomao@yahoo.com.br, ffinger@ufv.br (5)Universidade Federal da Paraíba, Departamento de Ciências Fundamentais e Sociais, Campus II, CEP 58397-000 Areia, PB, Brazil. E-mail: elizanilda@cca.ufpb.br
\end{abstract}

\begin{abstract}
The objective of this work was to evaluate the action of paclobutrazol (PBZ) on the growth and ornamental value of two pepper accessions and two commercial cultivars of ornamental pepper - Biquinho Vermelha and Bode Amarela. A PBZ aqueous solution $(250 \mathrm{~mL})$ was used to soak the substrate at $0,20,40$, and $60 \mathrm{mg} \mathrm{L}^{-1}$ a.i. concentrations when the plants had $12 \mathrm{~cm}$ height. At the end of plant growth, the follwoing parameters were evaluated: plant height, chlorophyll content in leaves, number of fruit and leaves, and canopy compactness at the time the plants reached maturity to be marketed, with $30 \%$ of ripe fruit. Irrespective of the applied PBZ concentration, plant height diminished, and chlorophyll content increased. PBZ did not improve the ornamental characteristics of the genotypes 'Biquinho Vermelha' and 2334PB, which resulted in unsuitable plants for market requirements. For the genotypes 2345PB and 'Bode Amarela', the application of $20 \mathrm{mg} \mathrm{L}^{-1}$ of PBZ is the most indicated, and it results in plants with adequate ornamental characteristics required by the national market of flowers and ornamental plants.
\end{abstract}

Index terms: Capsicum annuum, Capsicum chinense, chlorophyll, growth regulator.

\section{Crescimento e qualidade de pimentas ornamentais em vaso tratadas com paclobutrazol}

\begin{abstract}
Resumo - O objetivo deste trabalho foi avaliar a ação do paclobutrazol (PBZ) sobre o crescimento e valor ornamental de dois acessos e duas cultivares comerciais de pimenta ornamental - Biquinho Vermelha e Bode Amarela. Uma solução aquosa de $250 \mathrm{~mL}$ de PBZ foi adicionada aos vasos com 0, 20, 40 e $60 \mathrm{mg} \mathrm{L}^{-1}$ i.a., quando as plantas apresentavam $12 \mathrm{~cm}$ de altura. Ao final do crescimento, determinaram-se os seguintes parâmetros: a altura das plantas, o teor de clorofila das folhas, o número de frutos e de folhas, e a compacidade da parte aérea no estádio de maturidade das plantas, com $30 \%$ de frutos maduros. Independentemente da concentração de PBZ aplicada, houve redução da altura das plantas e aumento da concentração de clorofila nas folhas. O PBZ não melhorou as características ornamentais dos genótipos 'Biquinho Vermelha' e 2334PB, o que resultou em plantas inadequadas aos requisitos do mercado. Para os genótipos 2345PB e 'Bode Amarela', a aplicação de $20 \mathrm{mg} \mathrm{L}^{-1}$ de PBZ é a mais indicada e resulta em plantas com características ornamentais adequadas requeridas pelo mercado nacional de flores e plantas ornamentais.
\end{abstract}

Termos para indexação: Capsicum annuum, Capsicum chinense, clorofila, regulador de crescimento.

\section{Introduction}

The market for potted ornamental chilli pepper has increased considerably in Brazil and abroad (Finger et al., 2015). Ornamental peppers should show some important morphological characteristics that provide aesthetic value, which includes vivid foliage, small height, and colourful fruit contrasting with the green foliage (Rêgo et al., 2013).
For decorative purposes, it is necessary to use pepper cultivars adapted to the growth in small pots with a limited amount of substrate. However, there are only few commercial cultivars available in the market, since most plants from the genus Capsicum are of large size (Santos et al., 2013).

Paclobutrazol (PBZ) interferes with the first steps of the caurene oxidation pathway, preventing the formation of gibberellins, and acting as a negative 
control of the mechanisms related to gibberellins action, mainly by inhibiting the plant growth (Ribeiro et al., 2011). For these aspects, PBZ has been used with the purpose to reduce height in several species of ornamental plants (Rademacher, 2000). In the 'Pitanga' pepper (C. chinense), PBZ applied either by spraying on the leaves or put in the substrate was effective in reducing the plant height, plant diameter, and in increasing the leaf-chlorophyll content (Grossi et al., 2005). In the same work, the authors found that the reduction of plant height was proportional to the increase of PBZ concentration; however, no evaluation of the ornamental properties was performed. PBZ was also efficient in reducing the stem growth of sunflower and orchid plants (Wanderley et al., 2014a, 2014b). Potted sunflowers soaked with PBZ reduced the stem extension, which was reversed by spray of $\mathrm{GA}_{3}$ (Ribeiro et al., 2011).

The effectiveness of PBZ to reduce the plant growth varies according to plant stage of development, product concentration, species, cultivar, and time and mode of application (Rademacher, 2000; Mabvongwe et al., 2016). As PBZ is better absorbed by the root system, a direct application to the soil or pot substrate provides an increased efficacy at low concentrations (Currey \& Lopez, 2009).

Only few studies (Grossi et al., 2005; Ribeiro, 2016; Sipioni et al., 2016) have reported the effects of PBZ in controlling the growth on peppers species from the genus Capsicum (C. annuum; $C$. bacccatum; $C$. chinense, and $C$. frutescens) with ornamental potential. Nevertheless, the results showed a great response variability in the four tested species. The demand for ornamental peppers in Brazil is increasing year by year. However, only few commercial cultivars are available, considering the wide genetic variability in the genus Capsicum. The knowledge on the responses of a range of genotypes will increase the number of species with ornamental characteristics.

The objective of this work was to evaluate the effect of PBZ on the growth and ornamental value of two accessions and two commercial cultivars of pepper Biquinho Vermelha and Bode Amarela.

\section{Materials and Methods}

Four pepper genotypes with ornamental potential were used, two of them are the commercial cultivars
Bode Amarela and Biquinho Vermelha, both from the species $C$. chinense, and two are the accessions 2334PB and 2345PB of the species C. annuum and C. chinense, respectively, from the germplasm bank of Universidade Federal da Paraíba.

Seed were sown in polystyrene trays filled with the commercial substrate Bioplant (Bioplant Agrícola Ltda., Nova Ponte, MG, Brazil) in January 2013. The seedlings were transplanted into $900 \mathrm{~mL}$ pots no. 13 (11 cm height, $9.5 \mathrm{~cm}$ basal diameter, $13.5 \mathrm{~cm}$ top diameter), which contained the same substrate used for sowing. The plantlets were transplanted when showing two to three pairs of true leaves. The plants were grown in a greenhouse under natural conditions of light, in Viçosa, MG, Brazil (2045'S, 42 ${ }^{\circ} 51^{\prime} \mathrm{W}, 648 \mathrm{~m}$ altitude). During the transplanting, the substrate was fertilized with $2.5 \mathrm{~g}$ of formulated $\mathrm{N}-\mathrm{P}_{2} \mathrm{O}_{5}-\mathrm{K}_{2} \mathrm{O}$ 0-10-10. During the experiment, fertilization was performed every 20 days with $10 \mathrm{~g}$ of $\mathrm{N}-\mathrm{P}_{2} \mathrm{O}_{5}-\mathrm{K}_{2} \mathrm{O}$ 10-0-10 formula. The irrigation was made once or twice a day as needed.

At 15 days after the transplantation, when plants reached an average height of $12 \mathrm{~cm}, 250 \mathrm{~mL}$ paclobutrazol were directly applied to the growth substrate of each pot, at 20, 40, and $60 \mathrm{mg} \mathrm{L}^{-1} \mathrm{PBZ}$ (Cultar 250 SC, Syngenta, Brazil), corresponding to 5, 10 , and $15 \mathrm{mg}$ of the active ingredient, respectively. Control plants were watered with $250 \mathrm{~mL}$ of tap water. Plant height, chlorophyll-leaf content, number of fruit and leaves, and canopy compactness were evaluated when the plants reached the maturity to be marketed (30\% of ripe fruit).

The criteria used to establish the ornamental value of pepper plants in this research followed the standard by the Brazilian cooperative Veiling Holambra, São Paulo (Oliveira et al., 2007). Its quality standards take into account the following measurable characteristics: height (12-38.5 cm, in pots no. 13-15), canopy compactness, number of fruit per plant, maturation point; and quality (yellow and dry leaves, nutritional deficiencies, toxicity caused by chemicals). In order to meet the requirements of Veiling Holambra, the lot should show $90 \%$ uniformity in relation to the above mentioned characteristics.

Plant height was measured from the substrate level to the last fully expanded leaf. The chlorophyll content was indirectly estimated by the SPAD 502 chlorophyllmeter (Spectrum Technologies, Inc., Aurora, IL, USA), using the average of nine leaves, three at the basal part,

Pesq. agropec. bras., Brasília, v.53, n.3, p.316-322, Mar. 2018 DOI: $10.1590 / \mathrm{S} 0100-204 X 2018000300006$ 
three in the middle part, and three of the upper part of each plant. The canopy compactness was determined by taking two measures with $90^{\circ}$ angle between them, and dividing the smallest value by the largest one. The closest ratio indicate a complete round canopy (Ribeiro et al., 2011). The total numbers of fruit and leaves were counted in each plant, when plants had a minimum of $30 \%$ of ripe fruit (Segatto et al., 2013).

The experiment was carried out in a completely randomized design, with a $4 \times 4$ factorial arrangement (four pepper genotypes and four PBZ doses), and five replicates. Data were subjected to the analysis of variance and to the regression analysis. The models were chosen based on the significance of the regression coefficients, using t-test at $1 \%$ probability, for the coefficient of determination and the biological phenomenon. The Dunnett's test was used to compare means to the control, at $5 \%$ probability.

\section{Results and Discussion}

Irrespective of the genotype used, drenching the pot substrate with PBZ reduced the plant height with a similar adjusted regression model (Figure $1 \mathrm{~A}$ ). A significant reduction of plant height was reached with $20 \mathrm{mg} \mathrm{L}^{-1} \mathrm{PBZ}$ treatment, and no further height reduction occurred by increasing the dose of PBZ up to $60 \mathrm{mg} \mathrm{L}^{-1}$. The highest height reduction $(92.3 \%)$ - from $92.04 \mathrm{~cm}$ to $7.07 \mathrm{~cm}$ - was observed in the 2334PB accession, with $40 \mathrm{mg} \mathrm{L}^{-1} \mathrm{PBZ}$, according to the estimated curve (Figure $1 \mathrm{~A}$ and Figure 2). The least effect of PBZ was found for 'Bode Amarela', with 61\% reduction of plant height, and $20 \mathrm{mg} \mathrm{L}^{-1} \mathrm{PBZ}$ application. The reduction of plant height with PBZ occurs due to the inhibition of the gibberellin synthesis, which is responsible for the expansion and elongation meristem cells that will form the internode region (Rademacher, 2000). The variation of height reduction, observed in the tested genotypes, occurred because the effectiveness of PBZ varies according to the species, and also among varieties of the same species (Rademacher, 2000). Ribeiro (2016) worked with eight ornamental pepper genotypes from C. chinense and C. annuum, and found different PBZ responses between and within species. This suggests different levels and intensities of responses, involving alterations in the expression of specific genes, and in the activation of signaling pathways. In general, these genes act on several physiological phenomena; however, genus or species, associated to other factors, can determine the specific effect on the response (Brandão, 2010).

Veiling standards for plant height between $12-38.5 \mathrm{~cm}$ were adopted in the present work, in addition to others characteristics (canopy compactness, number of fruit per plant, yellowish and brittle leaves). The application of 40 and $60 \mathrm{mg} \mathrm{L}^{-1} \mathrm{PBZ}$ to 'Biquinho Vermelha' and the accession 2334PB were not able to fit them on this pattern. These doses caused a high degree of crinkled leaves, leaving them brittle and with an intensely stunted growth, and reduced their commercial and ornamental values. For those genotypes, the PBZ dose of $20 \mathrm{mg} \mathrm{L}^{-1}$ caused only mild symptoms of phytotoxicity, but they did not show satisfactory characteristics to be used as ornamental plants because they had an excessively low height of 9.8 and $13.6 \mathrm{~cm}$ for 'Biquinho Vermelha' and $2334 \mathrm{~PB}$, respectively (Figure 2). According to Brum et al. (2007), the height of ornamental plants should be 1.5 to 2 times that of the pot height; in this case, it should be between 16.5 and $22 \mathrm{~cm}$ for pots of $11 \mathrm{~cm}$ height. Thus, lower doses of PBZ, applied by drench or spray, may result in less phytotoxicity and smaller reduction of plant height. Grossi et al. (2005) applied PBZ on pepper 'Pitanga' (C. chinense), and found no toxicity effect when PBZ was applied on leaves; however, some plant characteristics were affected by the application, as branch length, which was reduced, consequently reducing the plant height. This behavior shows a great variability among genotypes and species of peppers in response to $\mathrm{PBZ}$.

The same symptoms of phytotoxicity were observed in all doses of PBZ for the accession 2334PB. In addition, the plants did not show a proper height for ornamental purposes, with an average height of $12 \mathrm{~cm}$ (Figure $1 \mathrm{~A}$ and Figure 2). In 'Bode Amarela' pepper, only the lowest dose of $20 \mathrm{mg} \mathrm{L}^{-1}$ of PBZ did not cause any symptom of phytotoxicity, and the plants had an adequate height of $18.5 \mathrm{~cm}$ for its use in ornamentation (Figure $1 \mathrm{~A}$ and Figure 2). For this cultivar, the doses of 40 and $60 \mathrm{mg} \mathrm{L}^{-1}$ promoted an excessive reduction of height and phytotoxic effects on the plants. Grossi et al. (2005) observed a linear reduction of plant height in 'Pitanga' ornamental pepper, which was proportional to the increasing doses of $\operatorname{PBZ}(5,10,15$, 30, and $60 \mathrm{mg}^{2}$ a.i. $\mathrm{L}^{-1} \mathrm{PBZ}$ ). The phytotoxic symptoms reported by these authors are corroborated by the present work for the doses of 30 and $60 \mathrm{mg}$ a.i. $\mathrm{L}^{-1}$. 
The plants of the 2345PB accession responded better to the plant growth regulator PBZ. They did not show any symptom of phytotoxicity for all applied doses, and had an appropriate average height of $19.3 \mathrm{~cm}$ for ornamentation (Figure $1 \mathrm{~A}$ and Figure 2).

Regardless of the dose and genotypes used, PBZtreated plants exhibited greener leaves, in comparison to the control. However, the pattern of increase of chlorophyll content varied among the genotypes (Figure 1 B). PBZ had a similar effect on chlorophyll content of Arabidopsis thaliana (Ribeiro et al., 2012a, 2012b) and 'Pitanga' pepper (Grossi et al., 2005). There are still doubts on whether the application of PBZ causes the increase of chlorophyll synthesis, or simply generates a "hub effect" due to the reduced leaf expansion (Davis et al., 1988).

In comparison to the control, the number of leaves was significantly reduced in all doses of PBZ, except for the $20 \mathrm{mg} \mathrm{L}^{-1}$ in 'Bode Amarela' (Table 1). Sankhla et al. (1986) have stated that the effect of PBZ on the production of new leaves depends on its applied concentration. At high PBZ concentrations, the production of leaves is reduced, whereas at low concentrations, the number of leaves is hardly changed. The density of leaves in an ornamental plant should be proportional to plant height, which results in a good canopy formation. In addition to the photosynthetic surface appropriate to the demands of the plant, the plant canopy should project to the sides of the pot, thus taking a circular shape and covering the substrate. However, the characteristics of each variety should be taken into account, as there are some of them that will not present this pattern for the canopy.

For the accessions $2345 \mathrm{~PB}$ and $2334 \mathrm{~PB}$, and for 'Bode Amarela', the number of fruit was not affected by the PBZ doses. However, plants of 'Biquinho Vermelha' had the number of fruit significantly reduced by the use of PBZ (Table 1). This result suggests the existence of a varietal effect not only for the plant height reduction, but also for the fruiting pattern. The inhibition of gibberellic acid biosynthesis promoted by PBZ may

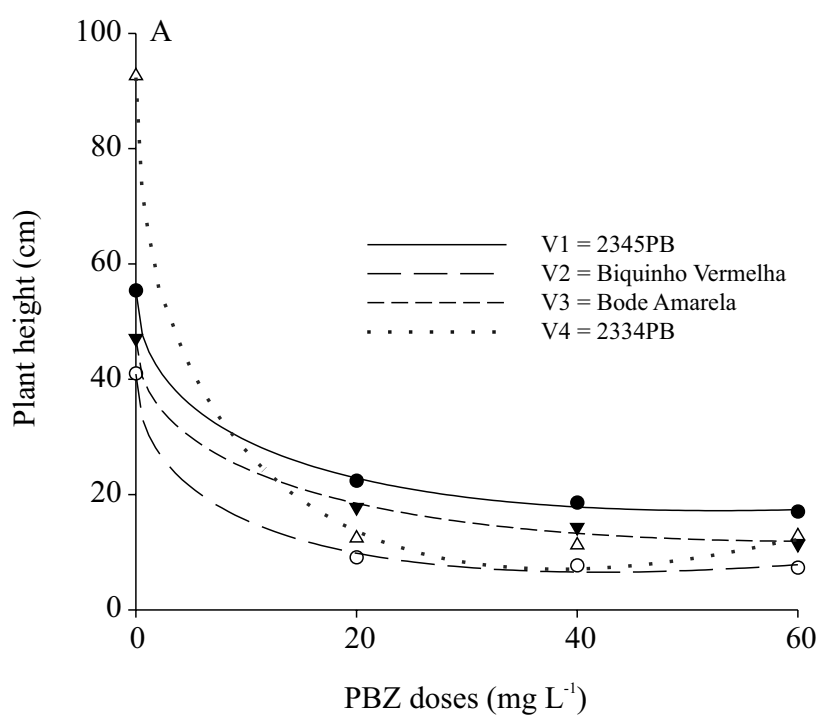

$$
\begin{array}{ll}
\hat{\mathrm{V}} 1=55.384-10.511^{* *} \sqrt{\mathrm{D}}+0.723^{* *} \mathrm{D} & \mathrm{R}^{2}=0.99 \\
\hat{\mathrm{V}} 2=40.912-10.619^{* *} \sqrt{\mathrm{D}}+0.819^{* *} \mathrm{D} & \mathrm{R}^{2}=0.99 \\
\hat{\mathrm{V}} 3=47.019-8.921^{* *} \sqrt{\mathrm{D}}+0.566^{* *} \mathrm{D} & \mathrm{R}^{2}=0.99 \\
\hat{\mathrm{V}} 4=92.376-27.560^{* *} \sqrt{\mathrm{D}}+2.225^{* *} \mathrm{D} & \mathrm{R}^{2}=0.99
\end{array}
$$

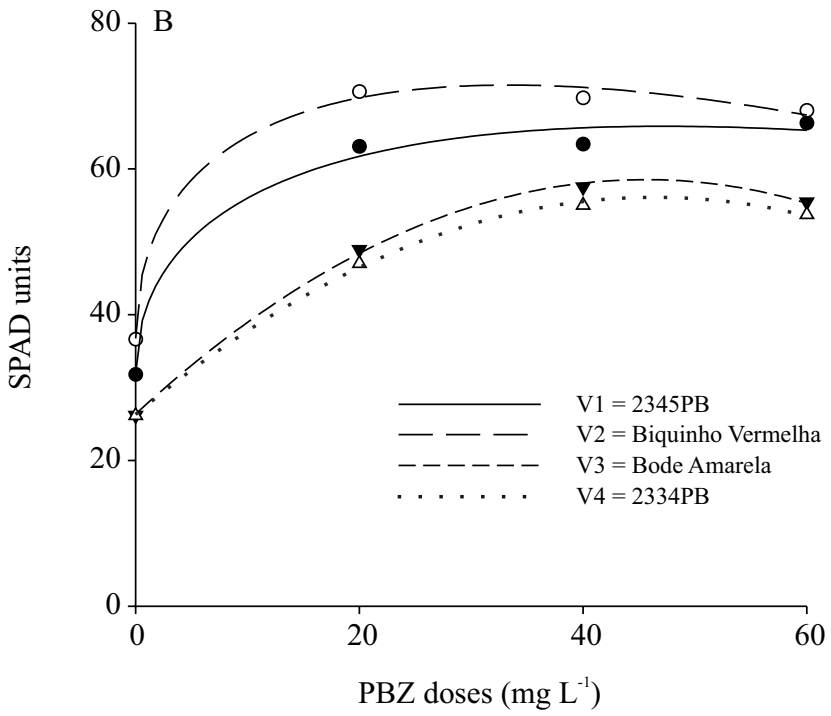

$$
\begin{array}{ll}
\hat{\mathrm{V}} 1=31.969+9.866 * * \sqrt{\mathrm{D}}-0.718^{* *} \mathrm{D} & \mathrm{R}^{2}=0.99 \\
\hat{\mathrm{V}} 2=36.727+12.069 * * \sqrt{\mathrm{D}}-1.047 * * \mathrm{D} & \mathrm{R}^{2}=0.99 \\
\hat{\mathrm{V}} 3=26.368+1.412^{* * D}-0.016^{* *} \mathrm{D}^{2} & \mathrm{R}^{2}=0.99 \\
\hat{\mathrm{V}} 4=26.312+1.283^{* * D}-0.014 * * \mathrm{D}^{2} & \mathrm{R}^{2}=0.99
\end{array}
$$

Figure 1. Plant height (A) and SPAD unit (B) according to the increasing levels of paclobutrazol (PBZ) applied to the Biquinho Vermelha and Bode Amarela cultivars and 2345PB and 2334PB accessions of pepper. **Significant by the t-test, at $1 \%$ probability. 


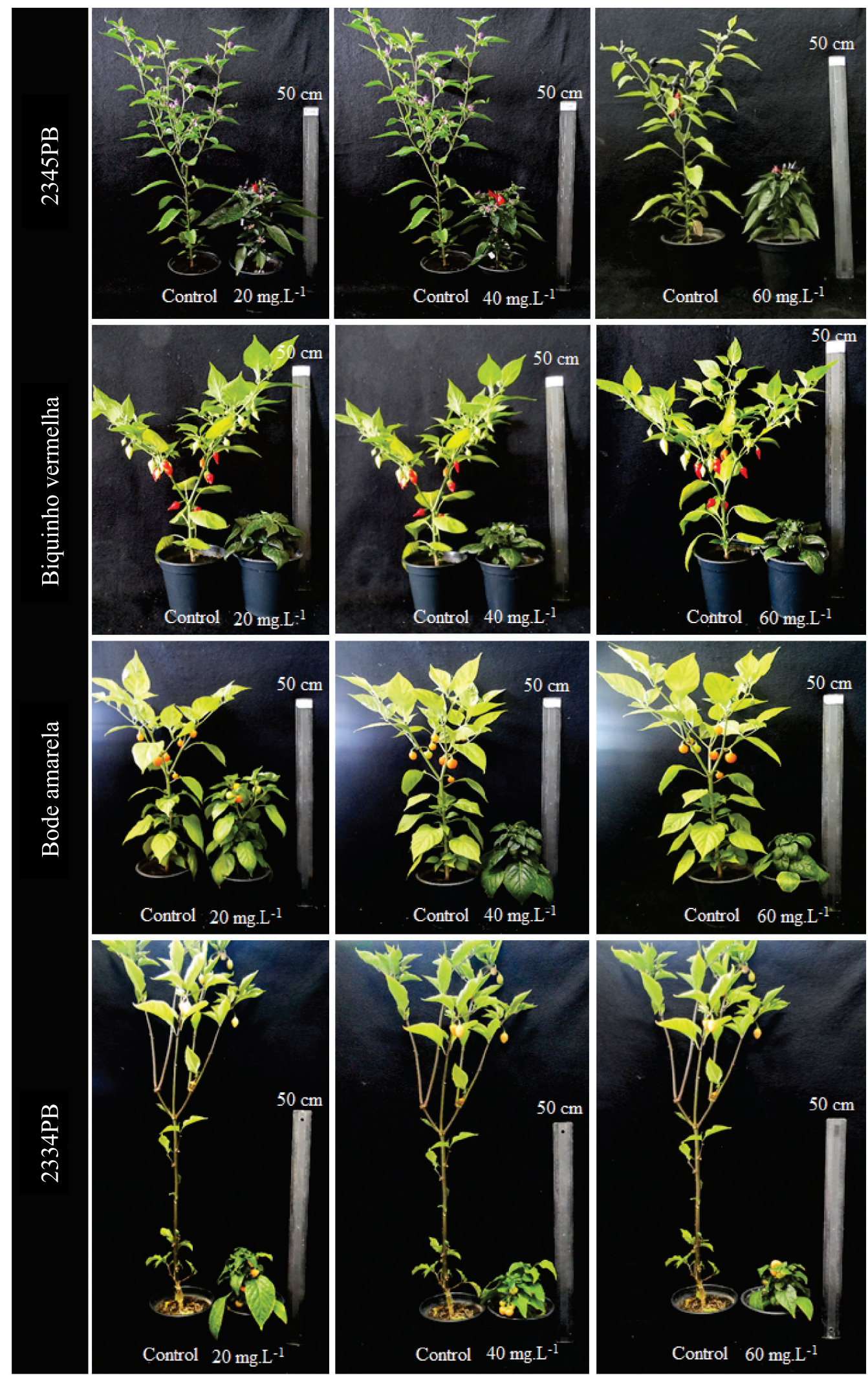

Figure 2. Images of ornamental peppers 2345PB, 'Biquinho Vermelha', 'Bode Amarela', and 2334PB, their controls, and plants treated with paclobutrazol (PBZ). 
cause flowering delay and, consequently, less fruit on the plant (Rademacher, 2000).

The canopy compactness was significantly higher than that of the control plants in all the applied PBZ doses just for the accession 2345PB. For the other cultivars, PBZ was not efficient in making the canopy more circular (Table 1). The canopy compactness of the plants was reduced with the application of PBZ, in agreement with Grossi et al. (2005) and Tinoco et al. (2011). This reduction of plant diameters is directly related to the reduction of internode elongation due to the inhibition of gibberellin biosynthesis. The reduction of plant canopy diameter results in a more compact plant. This feature is desirable and serves even as a quality standard for potted ornamental plants, including pots of chrysanthemum, May flower, gerbera and kalanchoe (Noman et al., 2017).

According to the results, the use of $20 \mathrm{mg} \mathrm{L}^{-1} \mathrm{PBZ}$ in the commercial cultivar Bode Amarela, and of 20 or 40 $\mathrm{mg} \mathrm{L}^{-1} \mathrm{PBZ}$ in plants of the accession 2345PB offer to the plants a suitable height for the use in ornamentation, without causing symptoms of phytotoxicity. For the commercial cultivar Biquinho Vermelha and for the

Table 1. Number of fruit, number of leaves, and canopy compactness of two cultivars and two accessions of pepper treated with paclobutrazol $(\mathrm{PBZ})^{(1)}$.

\begin{tabular}{lcccc}
\hline \multirow{2}{*}{ Genotype } & \multicolumn{4}{c}{ PBZ $\left(\mathrm{mg} \mathrm{L}^{-1}\right)$} \\
\cline { 2 - 4 } & 0 & \multicolumn{4}{c}{ Number of fruit } \\
2345PB & \multicolumn{4}{c}{40} \\
Biquinho Vermelha & 40.40 & $6.20^{*}$ & $5.60^{*}$ & $2.00^{*}$ \\
Bode Amarela & 7.40 & $14.20^{\text {ns }}$ & $10.60^{\text {ns }}$ & $3.60^{\text {ns }}$ \\
2334PB & 8.00 & $9.20^{\text {ns }}$ & $14.00^{\text {ns }}$ & $15.80^{\text {ns }}$ \\
\hline & \multicolumn{4}{c}{ Number of leaves } \\
2345PB & 71.40 & $44.00^{*}$ & $19.20^{*}$ & $25.80^{*}$ \\
Biquinho Vermelha & 115.40 & $37.00^{*}$ & $37.60^{*}$ & $32.80^{*}$ \\
Bode Amarela & 73.60 & $68.80^{\text {ns }}$ & $53.80^{*}$ & $42.20^{*}$ \\
2334PB & 76.80 & $64.20^{*}$ & $54.20^{*}$ & $57.40^{*}$ \\
\hline & & Canopy compactness \\
2345PB & 0.73 & $0.90^{*}$ & $0.89^{*}$ & $0.91^{*}$ \\
Biquinho Vermelha & 0.93 & $0.88^{\text {ns }}$ & $0.94^{\text {ns }}$ & $0.95^{\text {ns }}$ \\
Bode Amarela & 0.86 & $0.91^{\text {ns }}$ & $0.96^{\text {ns }}$ & $0.96^{\text {ns }}$ \\
2334PB & 0.95 & $0.84^{\text {ns }}$ & $0.91^{\text {ns }}$ & $0.93^{\text {ns }}$ \\
\hline
\end{tabular}

${ }^{(1)}$ Means followed by * differ from the control $\left(0 \mathrm{mg} \mathrm{L}^{-1} \mathrm{PBZ}\right)$ by the Dunnett's test, at $5 \%$ probability. ${ }^{\text {ns } N o n s i g n i f i c a n t . ~}$ accession 2334PB, new experiments using lower doses PBZ are necessary to determine the optimal dose of this plant growth regulator which could give aesthetic value to these plants for their use as ornamental plants.

\section{Conclusions}

1. For the genotypes 2345PB and 'Bode Amarela', the application of $20 \mathrm{mg} \mathrm{L}^{-1}$ of paclobutrazol is the most indicated one, and results in plants with adequate ornamental characteristics, which are required by the national market of flowers and ornamental plants.

2. The application of paclobutrazol does not improve the ornamental characteristics of the genotypes 'Biquinho Vermelha' and 2334PB, which may result in unsuitable plants for the market requirements.

\section{Acknowledgments}

To Conselho Nacional de Desenvolvimento Científico e Tecnológico (CNPq), to Coordenação de Aperfeiçoamento de Pessoal de Nível Superior (Capes), and to Fundação de Amparo à Pesquisa do Estado de Minas Gerais (Fapemig), for financial support.

\section{References}

BRANDÃO, A.D. Efeito da giberelina $\mathbf{A}_{3}$ e do paclobutrazol no metabolismo de carboidratos e expressão gênica em plântulas de cana-de-açúcar (Saccharum sp.). 2010. 255p. Tese (Doutorado em Biologia Vegetal) - Instituto de Biologia, Universidade Estadual de Campinas, Campinas.

BRUM, B.; SANTOS, V.J. dos; RODRIGUES, M.A.; BELLÉ, R.A.; LOPES, S.J. Crescimento, duração do ciclo e produção de inflorescências de crisântemo multiflora sob diferentes números de despontes e tamanhos de vasos. Ciência Rural, v.37, p.682-689, 2007. DOI: $10.1590 /$ S0103-84782007000300013.

CURREY, C.J.; LOPEZ, R.G. Applying plant growth retardants for height control. 2009. Available at: $<$ https://www.extension. purdue.edu/extmedia/ho/ho-248-w.pdf $>$. Accessed on: Apr. 15 2016.

DAVIS, T.D.; STEFFENS, G.L.; SANKHLA, N. Triazole plant growth regulators. Horticultural Reviews, v.10, p.63-105, 1988. DOI: $10.1002 / 9781118060834 . c h 3$.

FINGER, F.L.; SILVA, T.P. da; SEGATTO, F.B.; BARBOSA, J.G. Inhibition of ethylene response by 1-methylcyclopropene in potted ornamental pepper. Ciência Rural, v.45, p.964-969, 2015. DOI: $10.1590 / 0103-8478 \mathrm{cr} 20131386$.

GROSSI, J.A.S.; MORAES, P.J. de; TINOCO, S. de A.; BARBOSA, J.G.; FINGER, F.L.; CECON, P.R. Effects of paclobutrazol on growth and fruiting characteristics of 'Pitanga' ornamental pepper. Acta Horticulturae, v.683, p.333-336, 2005. DOI: 10.17660/ActaHortic.2005.683.41. 
MABVONGWE, O.; MANENJI, B.T.; GWAZANE, M.; CHANDIPOSHA, M. The effect of paclobutrazol application time and variety on growth, yield, and quality of potato (Solanum tuberosum L.). Advances in Agriculture, v.2016, article ID 1585463, 2016. DOI: 10.1155/2016/1585463.

NOMAN, A.; AQEEL, M.; DENG, J.; KHALID, N.; SANAULLAH, T.; SHUILIN, H. Biotechnological advancements for improving floral attributes in ornamental plants. Frontiers in Plant Science, v.8, article 530, 2017. DOI: 10.3389/fpls.2017.00530.

OLIVEIRA, R.; POZZEBON, M; HECK, E. van. Veiling Holambra - trading Brazilian flowers in the international market enabled by IT. Journal of Information Technology Case and Application Research, v.9, p.38-58, 2007. DOI: 10.1080/15228053.2007.10856106.

RADEMACHER, W. Growth retardants: effects on gibberellin biosynthesis and other metabolic pathways. Annual Review of Plant Physiology and Molecular Biology, v.51, p.501-531, 2000. DOI: 10.1146/annurev.arplant.51.1.501.

RÊGO, E.R. do; RÊGO, M.M.; FINGER, F.L.; NASCIMENTO, N.F.F.; NASCIMENTO, M.F.; CORTEZ DOS SANTOS, R.M. Phenotypic variability and importance of characters in a $F_{2}$ segregating generation of ornamental chili (Capsicum annuum). Acta Horticulturae, v.1000, p.493-496, 2013. DOI: 10.17660/ ActaHortic.2013.1000.70.

RIBEIRO, D.M.; ARAÚJO, W.L.; FERNIE, A.R.; SCHIPPERS, J.H.M.; MUELLER-ROEBER, B. Action of gibberellins on growth and metabolism of Arabidopsis plants associated with high concentration of carbon dioxide. Plant Physiology, v.160, p.1781-1794, 2012a. DOI: 10.1104/pp.112.204842.

RIBEIRO, D.M.; ARAÚJO, W.L.; FERNIE, A.R.; SCHIPPERS, J.H.M.; MUELLER-ROEBER, B. Translatome and metabolome effects triggered by gibberellins during rosette growth in Arabidopsis. Journal of Experimental Botany, v.63, p.2769-2786, 2012b. DOI: 10.1093/jxb/err463.

RIBEIRO, D.M.; MÜLLER, C.; BEDIN, J.; ROCHA, G.B.; BARROS, R.S. Effects of autoclaving on the physiological action of paclobutrazol. Agricultural Science, v.2, p.191-197, 2011. DOI: 10.4236/as.2011.23026.
RIBEIRO, W.S. Ação do paclobutrazol e do 1-MCP sobre a qualidade de espécies ornamentais de Capsicum. 2016. 72p. Tese (Doutorado) - Universidade Federal de Viçosa, Viçosa.

SANKHLA, N.; DAVIS, T.D.; JOLLEY, V.D.; UPADHYAYA. A. Effect of paclobutrazol on the development of iron chlorosis in soybeans. Journal of Plant Nutrition, v.9, p.923-934, 1986. DOI: 10.1080/01904168609363492.

SANTOS,R.M.C.;NASCIMENTO,N.F.F.;BORÉM,A.;FINGER, F.L.; CARVALHO, G.C.; NASCIMENTO, M.F.; LEMOS, R.C.; RÊGO, E.R.; RÊGO, M.M. Ornamental pepper breeding: could a chili be a flower ornamental plant? Acta Horticulturae, v.1000, p.451-456, 2013. DOI: 10.17660/ActaHortic.2013.1000.63.

SEGATTO, F.B.; FINGER, F.L.; BARBOSA, J.G.; RÊGO, E.R.; PINTO, C.M.F. Effects of ethylene on the post-production of potted ornamental peppers (Capsicum annuum L.). Acta Horticulturae, v.1000, p.217-222, 2013. DOI: 10.17660/ActaHortic.2013.1000.28.

SIPIONI, M.S.; FIRMINO JÚNIOR, J.L.; DIAS, P.H.R.; STEINER, F. Paclobutrazol and cattle manure use improves the quality of pepper seedlings. Scientia Agraria Paranaensis, v.15, p.332-337, 2016.

TINOCO, S.A.; GROSSI, J.A.S.; AZEVEDO, A.A.; BARBOSA, J.G.; SANTOS, N.T. Produção e qualidade de plantas de gerânio zonal (Pelargonium x hortorum L.H. Bailey) em resposta à aplicação de clormequat, daminozide e paclobutrazol via foliar. Revista Brasileira de Horticultura Ornamental, v.17, p.149158, 2011. DOI: 10.14295/rbho.v17i2.711.

WANDERLEY, C. da S.; FARIA, R.T. de; REZENDE, R. Crescimento de girassol como flor em vaso em função de doses de paclobutrazol. Revista Ceres, v.61, p.35-41, 2014a. DOI: 10.1590/ S0034-737X2014000100005.

WANDERLEY, C. da S.; FARIA, R.T. de; VENTURA, M.U.; VENDRAME, W. The effect of plant growth regulators on height control in potted Arundina graminifolia orchids (Growth regulators in Arundina graminifolia). Acta Scientiarum. Agronomy, v.36, p.489-494, 2014b. DOI: 10.4025/actasciagron. v36i4.18085.

Received on February 8, 2017 and accepted on June 29, 2017

Pesq. agropec. bras., Brasília, v.53, n.3, p.316-322, Mar. 2018

DOI: 10.1590/S0100-204X2018000300006 